Esta publicación cientifica en formato digital es continuidad de la revista impresa ISSN-Versión Impresa 0798-1406 / ISSN-Versión on line 2542-3185Depósito legal pp
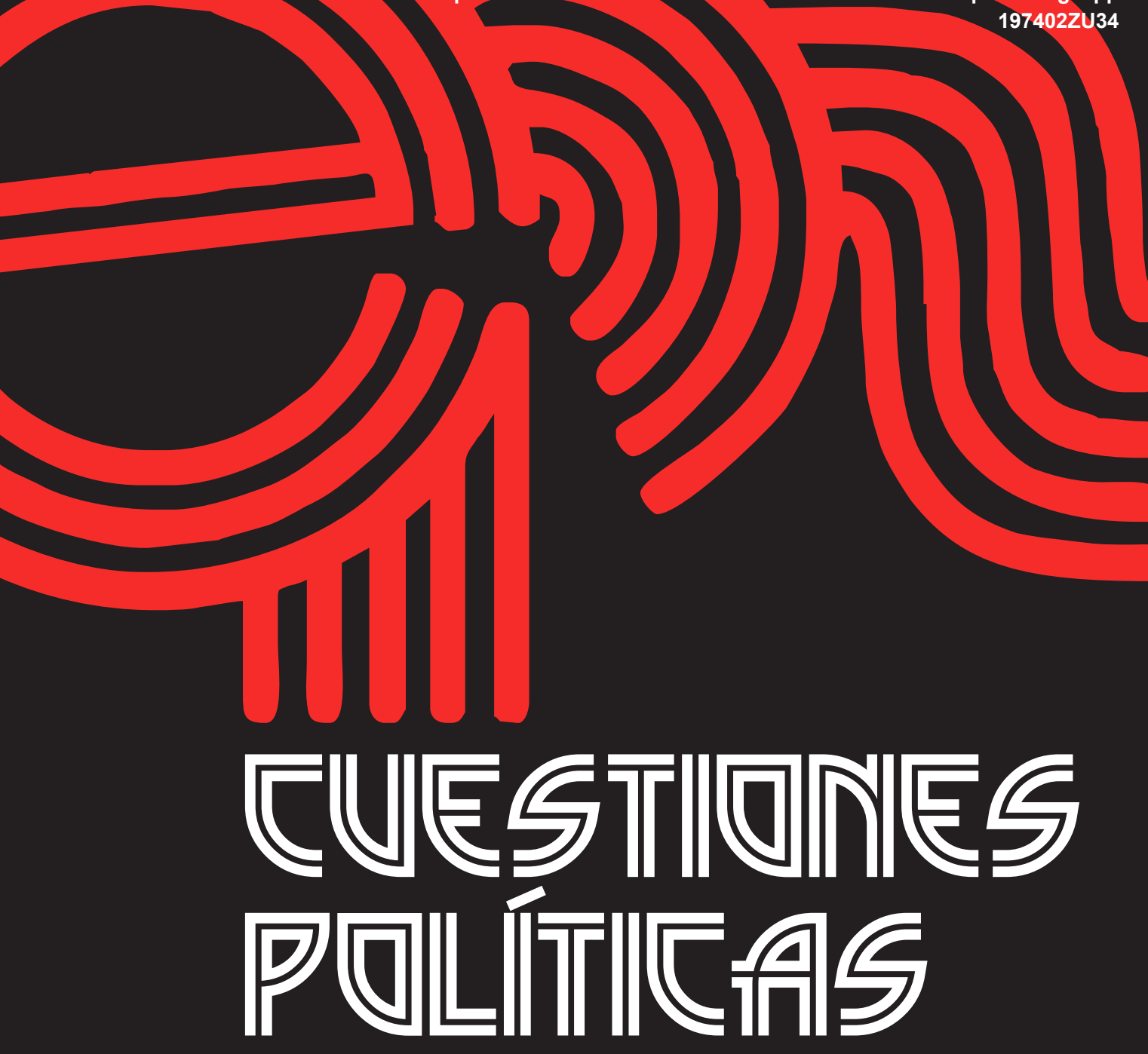

Instituto de Estudios Políticos y Derecho Público "Dr. Humberto J. La Roche" de la Facultad de Ciencias Jurídicas y Políticas de la Universidad del Zulia Maracaibo, Venezuela
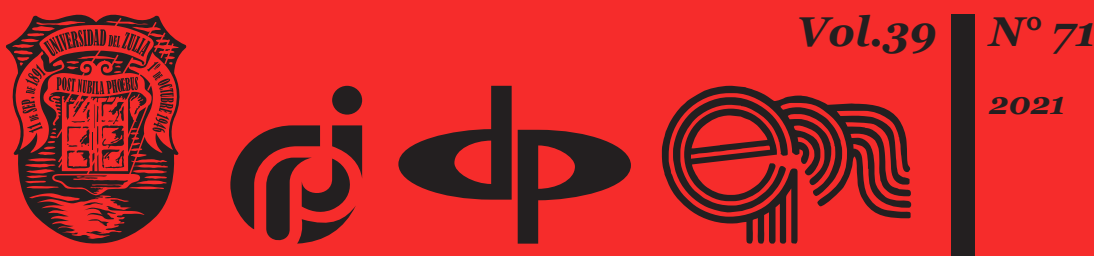


\title{
European Union as a Set of New Values in State-Building Processes in EU Enlargement Candidate Countries
}

\author{
DOI: https://doi.org/10.46398/cuestpol.3971.03
}

\author{
Elvira M. Gerasymova* \\ Svitlana V. Kutsepal ** \\ Zorina S. Vykhovanets *** \\ Olena P. Kravchenko **** \\ Nataliia F. Yukhymenko *****
}

\begin{abstract}
The aim of the research was to analyze the latest values of the EU in the context of their adaptation in the process of statebuilding in the candidate countries for enlargement with a view to reforming the legal field of the States. The main method was the observation method as a component of the experimental procedure with subsequent interpretation of the results (description). The results of the study demonstrate the axiological importance of the EU's main values. At the same time, the need for a gradual implementation of reforms in the sphere of state-building is argued, given the desirability of preserving national identity. It is concluded that the low level of adaptation of the EU pyramid of core values is corroborated and confirmed by statistical data, which requires a qualitative transformation of the reform strategy of the state-building processes of the candidate countries for EU enlargement. Scientific research was concerned with the search for the optimal and effective concepts of the integrated application of European values in the state-building processes in the candidate countries for EU enlargement.
\end{abstract}

Keywords: state building in Europe; adaptation of legislation; partnership with the EU; EU values; European integration.

* Doctor of Philosophy, Professor, Department of Department of Social Philosophy, Philosophy of Education and Educational Policy, Education and Science Management Faculty, National Pedagogical Dragomanov University, 01601, Kyiv, Ukraine. ORCID ID: https://orcid.org/oooo-0003-0046-8458

** Doctor of Philosophy, Professor, Department of Theoretical and Legal Disciplines, Poltava Law Institute, Yaroslav Mudryi National Law University, 36011, Poltava, Ukraine. ORCID: https://orcid. org/oooo-0003-3804-6031

*** PhD in Philosophy, Lecturer, Department of Foreign Languages, National Pirogov Memorial Medical University, 21018, Vinnytsya, Ukraine. ORCID ID: https://orcid.org/oooo-0002-1653-5873

**** PhD in Philosophy, Associate Professor, Department of Philosophy and Social Anthropology named after Professor I.P. Stogniy, Faculty of History and Social and Psychological Education, Hryhorii Skovoroda University, 08401, Pereiaslav, Ukraine. ORCID: https://orcid.org/oooo-0002-8736-8128

****** PhD in Philosophy, Associate Professor, Department of Philosophy and Social Anthropology named after Professor I.P. Stogniy, Faculty of History and Social and Psychological Education, Hryhorii Skovoroda University, 08401, Pereiaslav, Ukraine. ORCID ID: https://orcid.org/oooo-0001-7739-9716 


\section{La Unión Europea como conjunto de nuevos valores en los procesos de construcción del Estado en los países candidatos a la ampliación de la UE}

\section{Resumen}

El objetivo de la investigación fue analizar los últimos valores de la UE en el contexto de su adaptación en el proceso de construcción del Estado en los países candidatos a su ampliación con vistas a la reforma del ámbito jurídico de los Estados. El método principal fue el método de observación como componente del procedimiento experimental con posterior interpretación de los resultados (descripción). Los resultados del estudio demuestran la importancia axiológica de los principales valores de la UE. Al mismo tiempo, se argumenta la necesidad de una implementación gradual de las reformas en la esfera de la construcción del Estado, dada la conveniencia de preservar la identidad nacional. Se concluye que el bajo nivel de adaptación de la pirámide de valores principales de la UE está corroborado y confirmado por datos estadísticos, lo que requiere una transformación cualitativa de la estrategia de reforma de los procesos de construcción del Estado de los países candidatos a la ampliación de la UE. La investigación científica se ocupó de la búsqueda de los conceptos óptimos y eficaces de la aplicación integrada de los valores europeos en los procesos de construcción del Estado en los países candidatos a la ampliación de la UE.

Palabras clave: construcción del Estado en Europa; adaptación de la legislación; asociación con la UE; valores de la UE; integración europea.

\section{Introduction}

The EU values are common to member states, in a society of inclusion, tolerance, justice, solidarity and non-discrimination. These values are an integral part of the European way of life and the vector of reforms of the candidate countries for EU membership (Dines et al., 2020). Human dignity, freedom, democracy, equality, rule of law, human rights, among other things, remain the EU values. In turn, the values underlying European value integration have been widely discussed in recent years. Long discussions have shown that interpretations of these common values may differ, as may the process of their gradual implementation in the legal field of the state. Over the last decade, the EU's popularity among its citizens has decreased. In just a few years, EU leaders have witnessed a serious shift from a permissive consensus to "deterrent differences" (Wolczuk, 2019: 
Elvira M. Gerasymova, Svitlana V. Kutsepal, Zorina S. Vykhovanets, Olena P. Kravchenko y Nataliia F. Yukhymenko

63). The deterioration of the EU's image has created the conditions to call the legitimacy of the integration project into question. In the search for narratives, values can reappear in institutional communication.

The gradual actualization of the enlargement of the European Union, the search by candidate countries for EU membership of the optimal vectors of reforms justifies the transformation of the value benchmarks of states with the preservation of their own national identity. the practice of Ukraine deserves special attention. This state, despite the existence of internal conflict with the intervention of the aggressor country to it, does not deviated from the declared European values. The movement towards the European community is being slowed down by unfavourable geopolitical tendencies, Russia's hybrid aggression, and the outbreak of a global pandemic (Herasymchuk et al., 2020).

Moreover, despite the variability of approaches to European integration processes, the vector of driving change in Ukraine remains unchanged. Ukraine's European integration is a multi-level, dynamic and long process with a complex and sometimes dramatic evolution that depends on many internal and external factors (Yakymenko, 2020). Since Ukraine's independence, the European Union has been actively influencing its statebuilding processes. This is evidenced, among other things, by the Partnership and Cooperation Agreement signed in 1994 (Verkhovna Rada of Ukraine, 1994). At the same time, Ukraine's ratification of the Association Agreement with the European Union (Verkhovna Rada of Ukraine, 2014) qualitatively transformed the approach to domestic reform in all spheres of life. This regulatory act created the background for the latest approaches to statebuilding. At the same time, the legal analysis of the Association Agreement gives grounds to assert that it is already becoming an archaic document in fragments and does not correspond to modern realities and the potential of relations between Ukraine and the EU. Therefore, a comprehensive revision of this document should be on the agenda in order for Ukraine to actively enter EU industry markets. The renewal of the Association Agreement will provide a new quality of cooperation in key areas of sectoral integration (Stefanishyna, 2020).

It is worth noting that the new challenges also make adjustments to the partnership's priorities. Namely, the fight against COVID-19 raises priority issues of expanding cooperation in the field of health and pharmaceuticals, the introduction of new contactless technologies, strengthening business cooperation and employment guarantees (United Nations Ukraine, 2020). It should be noted that, on the one hand, the current technical assistance and financial resource potential do not correspond to the scale of transformation issues that países candidatos faces in the context of sectoral integration. On the other hand, acuerdos de asociación existentes entrelos Estados miembros y la UE does not contain the ultimate mobilizing goal, 
that is the prospects of EU membership. In general, there is reason to believe that progress and achievements have been made on the way towards Europe: from active political dialogue to the implementation of a number of European norms in a number of sectors. Progress towards the EU is, however, limited and complicated by a number of unfavourable internal factors, including corruption, socio-economic problems, the quality of the public administration system, limitations and failures of government policy, and so on.

Unfortunately, the states have not managed to effectively transform the course of European integration into socio-economic changes appreciable for ordinary citizens. It is obvious that the overall results of European integration, as well as the process of the EU enlargement candidate countries' further development and implementation of European values of state-building will be determined by how effectively countries will overcome its internal problems (Yermolenko, 2020). At this stage of EU enlargement candidate countries state-building, the countries and society face the task not so much of legislative enshrinement of fundamental European values, as of their further effective implementation in everyday life.

Given the above, the aim of the article is to consider the values of the European Union as a driving factor of state-building in EU enlargement candidate countries state-building in the context of the legal sphere's transformation of the states. The aim of the research involved he following research objectives: 1) analyze the set of EU values and identify the most effective ones for testing in the EU enlargement candidate countries state-building processes; 2) consider the results of the implemented reform actions on the territory of EU enlargement candidate countries and especially in Ukraine in the context of intensification of the countryEU dialogue; 3) outline the prospects for changes in state-building in EU enlargement candidate countries in terms of the European integration aspirations of the states.

\section{Methods and Materials}

The results of the study were obtained through the use of a set of practical and methodological tools tested at each stage of scientific research. The research procedure in terms of the stated aim of the article is shown in Figure 1. 
Elvira M. Gerasymova, Svitlana V. Kutsepal, Zorina S. Vykhovanets, Olena P. Kravchenko y Nataliia F. Yukhymenko

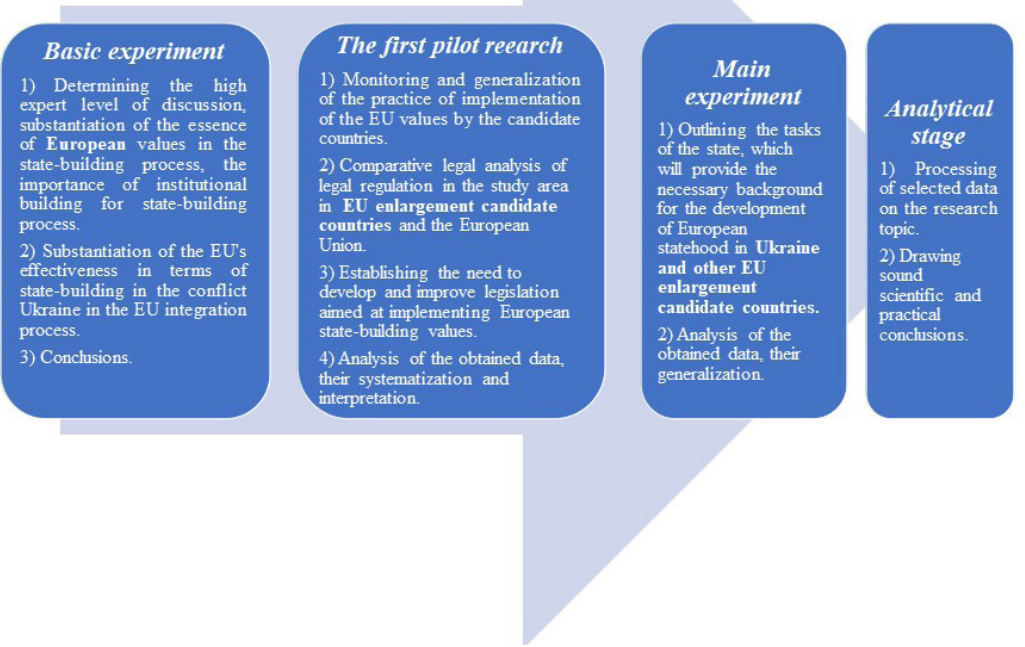

Figure 1: Abstract research design

The main hypothesis of the study is that certain ideas of European values, founded in the process of the EU's existence, can be actualized in the context of EU enlargement candidate countries' European integration. At the same time, the synthesis of these values, taking into account the national Ukrainian experience of integration, can become a strategic methodological and semantic background for the value reflection in both politics and economics.

Observation was the leading practical method of scientific research, which was aimed at vector passive study of the phenomena of adaptation of EU values in the legal sphere of EU enlargement candidate countries. This method allowed to reveal from the author's point of view the shortcomings of the gradual introduction of the concepts of EU integration into the current legislation of EU enlargement candidate countries; revealed imperfections in the right to implement and value vectors of European integration reforms; single out the positive aspects of further reforms for Ukraine and other EU enlargement candidate countries, provided that the optimal strategy is chosen; determine the low level of compliance with the pyramid of EU values and the obligations of the state of Ukraine in the direction of 
adapting sustainable European law enforcement practices, especially in the context of concluded agreements. The method of observation was included as an integral part of the experimental procedure and its results were interpreted in the article taking into account the need for further scientific research.

The research involved a strategy of qualitative comparative analysis, which allowed to overcome the distinction between quantitative and qualitative research methodologies in the context of the causal link between values and state-building processes in EU enlargement candidate countries. This method has been recently used in fragments in legal and political sciences, while it was actively tested in the article. The application of the logic of qualitative comparative analysis in the framework of scientific research allowed identifying the types of combinations of causes and effects of a particular type of values, distinguished on the basis of indicators of their successful testing in the legal sphere of EU enlargement candidate countries.

The multifaceted phenomenon of the adaptation of European values to the state-building processes implies the need to apply the approaches of several sciences, in particular, political, economic, sociological, historical and legal. So, the research involved such scientific methods as: system analysis (to study the set of political, economic, social, cultural and civilizational spheres of EU enlargement candidate countries integration); structural and functional analysis (to study the functional interdependence of various elements of values in the state-building processes); institutional method (to study and assess the role of different institutions in the process of adaptation of European values); formal legal method (for the analysis of the legal background of integration processes, first of all, the basic concepts of ensuring compliance with the European vector of reforms in EU enlargement candidate countries); method of scenarios (to build a forecast of prospects for the development of legal relations between EU enlargement candidate countries and the European Union in the event of the need to update the provisions of the association agreements).

The works ofleading scholars of the European Union and EU enlargement candidate countries were used in the course of the research. We analyzed 30 sources, among which special attention was paid to analytical and statistical reports on the implementation of European values in the legal sphere in EU enlargement candidate countries. The position of support for the currently proposed legislative reforms in light of their inadequacy to the countries realities was of particular importance. Working with authentic texts and relevant statistics allowed to form a comprehensive author's view of the subject of the article and to offer their own sound proposals for reform approaches to state-building. 
Elvira M. Gerasymova, Svitlana V. Kutsepal, Zorina S. Vykhovanets, Olena P. Kravchenko y Nataliia F. Yukhymenko

\section{Results}

Commitment to common ideals, principles and values is one of the most important conditions for the formation and stability of integration associations. The law does not establish values and ideals, it only enshrines and confirms their existence, is based on them and relies on them, which ensures its fullest and most effective implementation (European Parliament, 2021). Common values are the basis for the establishment of the institutional structure, defining the goals and tasks set by the integration association and their enshrinement in law. The commonality of the foundations gives the integration processes stability and a certain direction. The fundamental values remain largely unchanged and are generally preserved and proclaimed in all EU constituent acts. They can be formulated differently, undergo certain changes in the relevant documents, but they remain unchanged in their essential content.

The fundamental values laid down in the foundation of integration determine the nature and ways to achieve the goals it sets. In practice, such goals and objectives are formulated and implemented within the development strategy, which may also undergo certain changes at various stages of the evolution of the integration process depending on the internal and external conditions. Goals and directly related tasks are enshrined in regulations. These are, first of all, the founding treaties, as well as the acts adopted to ensure their observance.

When comparing the European Union with other centres of power in the geopolitical space, it is necessary to keep in mind a number of its fundamental features. The formation of a single market and the euro area, while contributing to the convergence of conditions in EU countries, smoothing the differences between national and regional models of members of these associations, did not deprive them of national identity (Organisation for Economic Co-operation and Development, 2019). The EU continues to consist of sovereign actors in international economic relations, which have transferred only part of their sovereignty to supranational bodies, choosing a European value as a guideline in state-building processes instead. Within the EU, states often act "for themselves", but join forces against third countries at the supranational level. "Europeanization of values and nationalization of interests" is taking place (Razumkov Centre, 2021).

It is important to emphasize that the countries of Central and Eastern Europe wishing to join the European Union must carry out public administration reforms at the national level in order to meet the Copenhagen and Madrid criteria for membership in the European Union. In turn, such reforms are expressed in the adaptation of EU values by implementing high-quality multisectoral reforms in order to bring national legal systems as close as possible to EU law. 
The question of the nature of European normative or rational discourse is based on the nature of the "values" referred to by the European institutions. Such values range from functional principles (transparency, dialogue) to broad political paradigms (democracy). Values underlie sociopolitical development. Moreover, values constitute the content of political institutions, outlining their purpose and logic of functioning, sustainability, and efficiency. Based on the modern understanding, European values should be considered not only in terms of ethical guidelines for the behaviour of citizens. First of all, European values are pragmatic principles, one of the main functions of which is the ability to maintain and increase the effectiveness of democratic institutions (European Values Info, 2006). According to the current practice, European values as a whole remain inviolable. Accordingly, it is impossible to build democratic institutions without the formation of European values.

In the Lisbon Treaty, as well as in the previous founding acts, an indication of the values underlying the creation, building, and functioning of the EU is set out in the Preamble. In formulating these values, the authors of the agreement largely used previous documents. As for the basic principles, we are talking about such incorruptible and inviolable values as the historical heritage of the peoples of Europe. It includes the cultural, religious and humanitarian heritage of the European continent. The wording is more than broad, especially given that the continent's historical heritage is extremely diverse and multifaceted. In this regard, the authors of the Treaty clarify that historical development leads to the formation of common or universal values. These are inalienable human rights and freedoms, as well as freedom, democracy, equality, and the rule of law. The cessation of the division of the European continent, the commitment to building a united Europe of the future are the results of historical evolution included in the Preamble.

It can be argued that European high culture developed in six stages, which led to the formation of the six most fundamental European values. The study showed that the following EU values can be identified in modern conditions, which are able to influence the state-building reforms in Ukraine (Figure 2). 


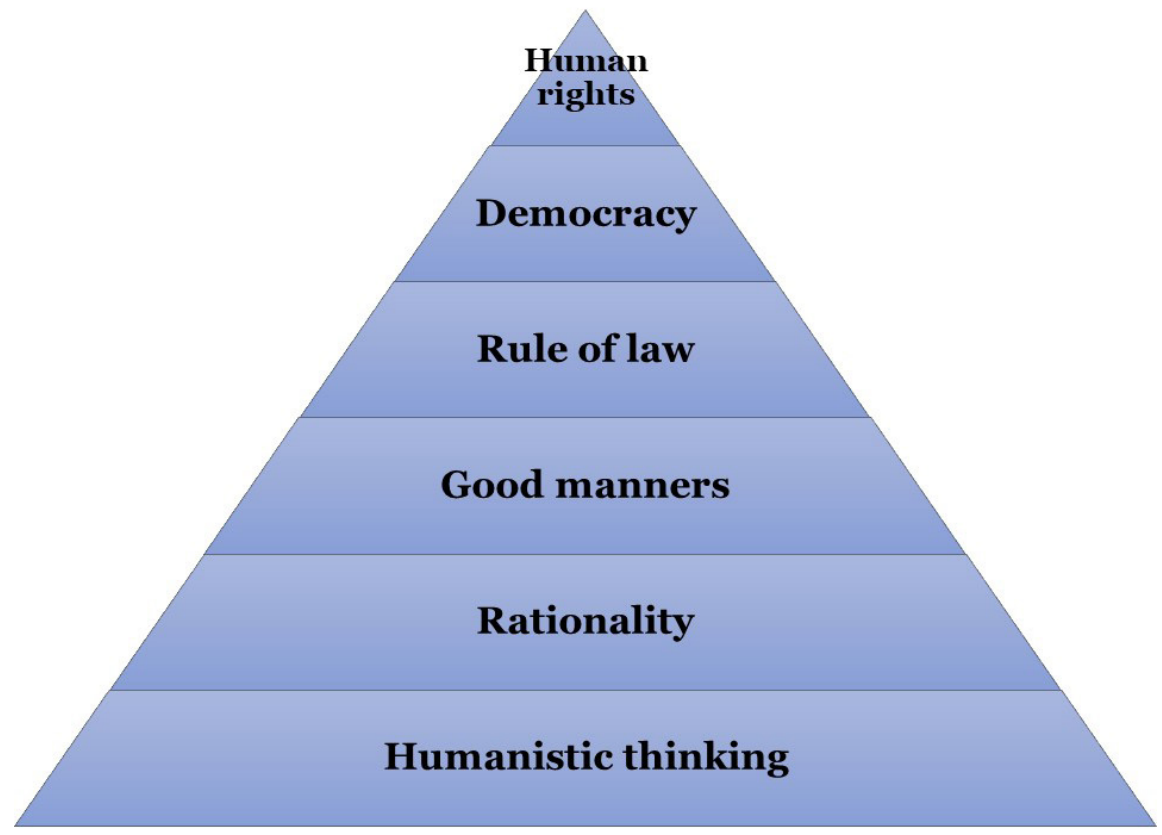

Figure 2: Pyramid of fundamental European values of state-building

From a legal point of view, the issue of respect for and observance of the fundamental values underlying the EU is inextricably linked to respect for human rights. So, it is the observance of fundamental human rights in the context of European integration that forms the most comprehensive and effective vector of national and foreign policy of any state that is trying to move closer to EU membership. The modern doctrine of human rights is, of course, Eurocentric. Moreover, respect for human rights is recognized in the EU as a leading concept for future generations.

At the same time, in the context of state-building, special attention is paid to the implementation of the rule of law in a particular state. In recent decades, international and European organizations have placed the rule of law at the heart of their prescriptions for economic, political and social reform. The EU's focus on the rule of law - as a shared value and tool for promoting democracy - dates back to the early 1990's, when EU institutions sought not only to democratize the EU's institutional framework but also to assess its role in the world. In this context, it is argued that the legitimacy of the EU as a "regulatory force" seems to be based on the ability to translate universal norms into more concrete policies (Lehne, 2020). Being both in 
the list of values on which the EU is based and in the status of the goal of EU foreign policy, the rule of law is called "intermediate" and "final" for the development and legitimation of a wide range of domestic and foreign policies. The internal and external dimensions are highly interdependent and interlinked, as the content of the rule of EU law has been developed and enriched through its external promotion.

The rule of law has entered EU policy as a policy guideline that was originally used in the EU's external activity to assess candidate countries' commitment to democracy and as a form of technical assistance. In managing domestic reforms in the former Soviet Union, the European Commission has gained experience and knowledge in a number of policy areas, which have previously been outside the EU's remit (National Democratic Institute, 2021). In just a couple of years, the institution has been able to develop its new enlargement policy and define its approach to promoting the rule of law. The enlargement process has contributed to the technification of the rule of law debate. However, in recent years, the rule of law has been a matter of concern in the EU, which has increased tensions between domestic and European actors. The politicization of the rule of law has become an opportunity for the European Commission to clarify its powers in relation to the Member States. Despite differing concepts on how to protect the rule of law at the supranational level, EU institutions seek to "promote", "strengthen" and "protect" the rule of law. Therefore, in both its internal and external activities, the European Commission uses the rule of law to set political priorities and, as a result, politicizes it and gives it new meanings depending on the political context.

In turn, the current stage of law and state-building in EU enlargement candidate countries i can be characterized as transformational, associated, on the one hand, with the desire to carry out necessary reforms, the formation of civil society, the rule of law, and on the other - with the need to protect human rights and freedoms. conditions for overcoming the crisis and thrive to accelerate European integration. It is clear that such a legal phenomenon as the role of law and its effectiveness in today's conditions is not the last among the many factors that influence these processes. Thus, Ukraine's international legal obligations determine the implementation of a set of reforms of national sectors in the context of strengthening the European vector of state development. Ukraine remains a priority partner of the European Union. The EU supports Ukraine in ensuring a stable, prosperous and democratic future for its citizens, and unwaveringly supports the independence, territorial integrity and sovereignty of Ukraine. The Association Agreement, including its Deep and Comprehensive Free Trade Area signed in 2014, is a key instrument for rapprochement between Ukraine and the EU, fostering political ties, strengthening economic ties and respecting common values. Ukraine continues its ambitious reform agenda to accelerate economic growth and improve the living conditions 
Elvira M. Gerasymova, Svitlana V. Kutsepal, Zorina S. Vykhovanets, Olena P. Kravchenko y Nataliia F. Yukhymenko

of its citizens. Priority reforms include the fight against corruption, judicial reform, constitutional and electoral reforms, improving the business climate and energy efficiency, public administration reform and decentralization. Since 2014, the EU and financial institutions have mobilized more than $€ 15$ billion in grants and loans to support the reform process with tough conditions for further progress.

At the same time, the current process of adaptation of European values in Ukraine is taking place in the conditions of an obvious deficit of European values, which allows us to draw analogies with the so-called process of "building capitalism without capitalists". However, there is an unstable and intermittent value transformation, which results in the formation of the elements of democratic values. The gradual modernization of the values of Ukrainian society has the potential to change ("correct") the essence of existing political institutions, to fill them with democratic content. The coherence of Ukrainian values with post-materialist European values creates an additional ground for a relatively rapid transformation.

Since Ukraine's independence in 1991, successive governments have failed to build effective state institutions. In the early 1990's, a group of entrepreneurs seized control of parliament, government, and the judiciary, passing laws in their favour and in the interests of political allies. In the future, the creation of a background for sustainable socio-economic development has not become the prerogative of public administration. The concept of "reform" has become synonymous with new ways of stealing the budget, dismantling the rule of law and masking corruption (Lough and Solonenko, 2016).

At the same time, the ratification of the Association Agreement (Verkhovna Rada of Ukraine, 2014) was a confirmation of the development of bilateral relations between Ukraine and the European Union. Moreover, this document legalized the choice of our state in favour of modern European values. Despite the progressive nature of the document at that time, it is gradually losing its relevance. Besides, much of the international legal obligations undertaken by the state under the Association Agreement remain unfulfilled. Referring to the legal background for ensuring compliance with Ukraine's obligations to adapt European values, it should be noted that currently the implementation of the Action Plan for the implementation of the Association Agreement (Cabinet of Ministers of Ukraine, 2017) is unsatisfactory (Cabinet of Ministers of Ukraine, 2020). In particular, the Ukraine Common Country Analysis report states that Ukrainian society is facing significant structural divisions and polarization, which affects not only the progress of state-building, but also the sustainability of the social foundation of reforms. The analysis identifies numerous development opportunities that should be prioritized and constantly updated to promote an integrated solution that will provide numerous positive changes in the 
development sectors of the state and sustainable common European value benchmarks (United Nations Ukraine, 2021).

It is especially reasonable to pay attention to the implementation of the concept of "rule of law" in Ukraine, enshrined at the constitutional level. For a long time, the position on the prospects of supporting and recognizing the rule of law with all its components was expressed by the Constitutional Court of Ukraine (2021). However, despite the enshrinement of one of the EU's most important values, it remains largely declarative. This is evidenced, among other things, by the indicators of the annual rule of law index in all countries of the world, which are summarized and published by the World Justice Project (2021). Such an analysis includes the following key indicators of the rule of law - 1) corruption; 2) observance of fundamental rights; 3) transparency and openness of the government; 4) the effectiveness of law enforcement; 5) restrictions on state institutions; 6) observance of order and security; 7) the state of justice. According to the World Justice Project Rule of Law Index 2020, Ukraine received a score of 0.51 out of 1 in 2020, where one means the absolute rule of law. In the overall ranking, Ukraine ranked $72^{\text {nd }}$ out of 128 countries, and 7 th in the regional division out of 14 countries in Eastern and Central Europe (World Justice Project, 2020). In general, occupying a rather low place in the above-mentioned overall ranking shows that Ukraine's approach to this EU benchmark is extremely slow.

At the same time, domestic changes in the vectors of reforms in EU enlargement candidate countries have led to a transformation of views on European values, which, unfortunately, have now receded into the background. The study allowed recording the emergence of negative phenomena that slow down or make it impossible to properly implement and protect the declared EU values in EU enlargement candidate countries. These factors are shown in Figure 3.

The analysis of the above-mentioned problems shows that each of them has its own subjective and objective reasons of origin and existence, and modern reform of the domestic legislation of the state is aimed at overcoming them.

In turn, the gradual implementation of European values, subject to moderate control by the EU, is possible by choosing one of the three types of reform strategies listed in Table 1 . At the same time, we can observe an uncontrolled mixing of all three types of reforms, for example, in Ukraine, which, according to the author, is the cause of significant problems in the development of European membership criteria in Ukraine. Undoubtedly, the European values must be adapted in a balanced way, taking into account national realities and national identity. In turn, Ukraine has now chosen the unappealable implementation of all European values, which cannot be fully adapted for Ukraine without taking into account the peculiarities of law enforcement and state-building. 
Elvira M. Gerasymova, Svitlana V. Kutsepal, Zorina S. Vykhovanets, Olena P. Kravchenko y Nataliia F. Yukhymenko

1

- The low level of legal culture and consciousness of the population of the state associated

with the constant leveling of the very essence and content of human rights;

- Loss of self-esteem, feelings of honorr and dignity, lack of thriving for self-development

2

- Lack of motivation to increase responsibility for the results of their activities or inaction, low level of public order;

- Declarative equality of branches of government, lack of effective implementation of the competence of local governments

3

- Levelling the implementation of civil control at all levels of public life and statehood;

- Impossibility and unwillingness to overcome the corruption components of the modern state apparatus;

- The gradual destruction of unstable ties between man, citizen, state and society, and others.

\section{Figure 3: Negative factors of introduction of European values in the state-building processes in EU enlargement candidate countries (Own creation).}

\section{Table 1. Types of strategy for reforming the state-building processes in the context of adaptation of European values (Own creation)}

\begin{tabular}{|c|c|c|}
\hline $\begin{array}{l}\text { Radical change of the old } \\
\text { (including the imperial) } \\
\text { institutions, a complete } \\
\text { break with the old } \\
\text { management structure } \\
\text { and rules, an attempt to } \\
\text { replace them with new } \\
\text { ones }\end{array}$ & $\begin{array}{l}\text { Maintaining continuity } \\
\text { between old and new } \\
\text { institutions }\end{array}$ & $\begin{array}{c}\text { Inconsistent } \\
\text { implementation of } \\
\text { institutional reforms }\end{array}$ \\
\hline $\begin{array}{l}\text { This strategy may involve } \\
\text { a radical break with the } \\
\text { institutions of "restricted } \\
\text { order" and an attempt to } \\
\text { replace them with institutions } \\
\text { of "open access order". This } \\
\text { strategy assumes high costs at } \\
\text { the initial stage, but a reduction } \\
\text { in the amount of resources } \\
\text { required and the cost of } \\
\text { overcoming the contradictions } \\
\text { between the old and new } \\
\text { institutions in the future }\end{array}$ & $\begin{array}{l}\text { This strategy envisages saving } \\
\text { resources for serious reforms, } \\
\text { building a new management system } \\
\text { and forming a new regulatory } \\
\text { framework. The situation of } \\
\text { certainty given the dominance } \\
\text { of old norms and rules does not } \\
\text { prevent long-term investment } \\
\text { in public goods. However, the } \\
\text { positive effect of this strategy } \\
\text { cannot be long-term. Over time, } \\
\text { contradictions between old } \\
\text { institutions ("restricted access") } \\
\text { and new requirements between } \\
\text { formal and informal norms may } \\
\text { escalate }\end{array}$ & $\begin{array}{l}\text { Involves coexistence of old } \\
\text { and new norms, rules and } \\
\text { mechanisms, which mostly } \\
\text { contradict each other, } \\
\text { aggravation of the situation } \\
\text { of uncertainty, aggravation } \\
\text { of contradictions between } \\
\text { formal and informal norms } \\
\text { and procedures. This strategy } \\
\text { motivates government } \\
\text { agencies to use contradictions } \\
\text { in their personal or narrow } \\
\text { group goals, achieving benefits } \\
\text { rather than investing in long- } \\
\text { term public goods }\end{array}$ \\
\hline
\end{tabular}


It is also expedient to focus on other candidate countries for accession to the EU. Thus, in June 2018, the EU Council agreed to intensify accession talks with both North Macedonia and Albania if states comply with a certain range of EU conditions. At the same time, negotiations have not been started in 2019. In March 2020, the methodology for expansion to the Western Balkans was revised. However, negotiations on the accession of North Macedonia and Albania, which have been candidate countries for many years, have not yet been opened. The EU-Turkey relationship on EU accession has now been further exacerbated by Turkey's foreign policy choices, its unilateral actions in the Eastern Mediterranean, and its position and initiatives on the Cypriot issue. In this context, even the fragmentary approbation of European values by this state does not create the proper basis for a stable relationship with the EU.

After two decades of intensive and powerful process of state-building, Bosnia and Herzegovina, unprecedented in modern European history, still demonstrates a significant number of negative factors, making it impossible to implement European values comprehensively. The process of integration into the EU is currently almost completely blocked and the country has not yet submitted its candidacy.

Despite the European Commission's aspirations and efforts to increase confidence in the accession process and give it a stronger political steering wheel and clear value benchmarks, the process of membership has already become a shadow of what it has been in previous decades, when it was considered the largest indicator of a successful EU foreign policy. Annual state reports published by the European Commission continue to serve as a useful barometer of reforms for each country and the implementation of the most significant European values. The EU today has become an international actor promoting democracy on its territory, in member states and even around the world.

His democratic commitments are in line with his leading value benchmarks. The EU has successfully managed to gain significant geopolitical influence and allow democratic transformations in the Balkans, for example, and in Ukraine. In this respect, the EU can be seen as an «intermediary» between candidate states as an active arbiter of value reform vectors.

\section{Discussion}

The study showed that the values of the European Union produce their direct impact on the processes of development and transformation of any state that aspires to become a full member of the EU. The pyramid of key values is sustainable and needs to be gradually introduced into the legal 
Elvira M. Gerasymova, Svitlana V. Kutsepal, Zorina S. Vykhovanets, Olena P. Kravchenko y Nataliia F. Yukhymenko

field of such candidate countries. Instead, the lengthy process of ensuring adherence to such values is not taken into account at all when choosing a European reform vector. Scholars support this position and point out that as a result of such actions the state receives an accumulation of declarative norms without mechanisms for their practical implementation (Fedorenko et al., 2019). It was stated that technical reforms are currently underway in EU enlargement candidate countries, which are manifested in the adoption of new regulations and the creation of new state institutions. EU enlargement candidate countries do not enter into disputes and negotiations with the European Union in the context of the implementation of EU values and standards. In this regard, blind copying of values can lead to negative consequences for the states, which will lose its iconic features developed over the years, and built a monolithic architecture of legislation. In this context, there is an active discussion on the selection of the most appropriate mechanisms for the implementation of European values.

Scholars state that the process of state-building creates a number of dilemmas of law enforcement and organizational nature in EU enlargement candidate countries (Babenko et al., 2020). The leading important dilemma concerns in Ukraine for example the question of whether it is correct to insist on the comprehensive adaptation of European values and the reconstruction of the state, which remains a shared hybrid aggression of the Russian Federation (Dzutsati, 2020). In this context, the European Union's approach is based on the assumption that integration into the EU through the gradual stabilization of state-building processes within the association will lead to internal tensions (Duleba, 2019). Another problem is relevant given the need to choose an approach to the renewed state-building process. With this in mind, two approaches proposed by scholars (Bargués and Morillas, 2021) are possible for testing: top-down (which focuses on building institutions and is technical in nature), and bottom-up (based on building participation, developing a democratic culture, civil society and reconciliation). Unfortunately, scholars have confirmed that current statebuilding missions and adaptation processes in EU enlargement candidate countries ignore the wider context and social factors and are focused mainly on the technical process of institutional building (Kharazishvili et al., 2021). Therefore, it can be argued that the formation of the most effective influence of EU values on state-building processes needs a broader context and understanding of national practice. This approach is important for the end result of the European integration process.

Addressing the pyramid of leading EU values and the state of their observance in EU enlargement candidate countries, scholars share the author's position on the low level of ensuring compliance with the declared postulates. Moskal (2021) emphasizes that Ukraine has currently no single approach to the interpretation of the rule of law. This, in turn, demonstrates the lack of consensus on an understanding of the European approach to the 
rule of law. Popadynets (2020) emphasizes that the fundamental human rights in EU enlargement candidate countries are also observed at a low level, which is only an indicator of the gradual establishment of democracy.

\section{Conclusions}

The European Union has an institutional structure designed to promote its values, affirm its objectives, serve the interests of its citizens and its Member States, and ensure the integrity, unity, effectiveness and coherence of its policies and actions. The study showed that the fundamental values of the EU are inviolable and require qualitatively new views on their implementation at the national level.

The rise of public interest in EU enlargement candidate countries in the legislation of the European Union, the essence and content of European values, and especially in ensuring the rule of law is historically justified. After many years when the law was mostly used to achieve political goals, the proclamation of its supremacy as the main priority of the state is undoubtedly a progressive integration step of the states into the international community. Today, the need to find a compromise between European values, society and the state becomes especially urgent.

Sectoral integration is a global, multi-vector and multi-speed process aimed at the gradual construction of modern Europe in EU enlargement candidate countries. An indicator of the effectiveness of the state's European integration activities is the level of implementation of the association agreements and concepts of the countries (in general and by sectors). Unfortunately, the current state of adaptation of European values remains unsatisfactory due to various subjective and objective factors.

The prospect of further research should be the development of the cross functional concept of integrated implementation of European values in the state-building processes in EU enlargement candidate countries, taking into account geopolitical factors and features of national identity. In this context, the decisive vector of the author's search should be the choice of optimal mechanisms for law enforcement and ensuring compliance with the constitutionally proclaimed principle of the rule of law.

\section{Bibliographic References}

BABENKO, Vitalina; BILETSKA Yana; PELYAK, Hanna. 2019. "Ukraine-EU: economic integration strategy" In: Geopolitics under Globalization. Vol. 3, No. 1, pp. 12-23. 
Elvira M. Gerasymova, Svitlana V. Kutsepal, Zorina S. Vykhovanets, Olena P. Kravchenko y Nataliia F. Yukhymenko

BARGUÉS, Pol; MORILLAS, Pol. 2021. "From democratization to fostering resilience: EU intervention and the challenges of building institutions, social trust, and legitimacy in Bosnia and Herzegovina" In: Democratization. Vol. 28, No. 7, pp. 1319-1337.

CABINET OF MINISTERS OF UKRAINE. 2017. Resolution on implementation of the Association Agreement between Ukraine on one side and the European Union, the European Atomic Energy Community and their Member States on the other side. Available online. In: https://zakon. rada.gov.ua/laws/show/1106-2017-\%Do\%BF\#Text. Consultation date: 03/04/2021.

CABINET OF MINISTERS OF UKRAINE. 2020. European Integration of Ukraine in 2020. Cabinet of Ministers of Ukraine, 16 p. Kyiv, Ukraine.

CONSTITUTIONAL COURT OF UKRAINE. 2021. Rule of Law. Catalogue of legal positions of the Constitutional Court of Ukraine (according to rulings, conclusions). Available online. In: https://ccu.gov.ua/storinkaknygy/34-verhovenstvo-prava. Consultation date: 03/04/2021.

DINES, Alexandra; AFONTSEV, Sergey; BALASH, Peter; KRUDU, Rodika; GALOYAN, Diana. 2020. Economic integration. Samuel Charap et al. (eds.), "On EU policy in the post-soviet space, pp. 53-79. Freiedrich Ebert Stiftung. Vienna, Austria.

DULEBA, Alexander. 2019. "Opportunities and problems in EU-Ukraine relations: actors' perceptions" In: International Issues \& Slovak Foreign Policy Affairs. Vol. 28, No. 1/2, pp. 47-72.

DZUTSATI, Valery. 2020. "Geographies of hybrid war: rebellion and foreign intervention in Ukraine” In: Small Wars \& Insurgencies. Vol. 32, No. 3 , pp. 441-468.

EUROPEAN PARLIAMENT. 2021. The protection of Article 2 TEU values in the EU. Available online. In: https://www.europarl.europa.eu/ factsheets/en/sheet/146/the-protection-of-article-2-teu-values-in-theeu. Consultation date: 03/04/2021.

EUROPEAN VALUES INFO. 2006. Definition of the Most Basic European Values and Their Significance for Our Modern Society. European Values Info, 46 p. Graz, Austria.

FEDORENKO, Kostyantyn; POLYAKOV, Leonid; KOZIY Ihor. 2019. Military-technical cooperation between Ukraine and the EU. Available online. In: http://www.ieac.org.ua/public/item/96-hromadskyimonitorynhspivpratsi-ukrainy-ta-yes-u-bezpekovii-sferi-policy-paper. Consultation date: 03/04/2021. 
HERASYMCHUK, Serhiy; MATIYCHYK, Yaroslav; KHYLKO, Maksym; FYLYPENKO, Artem; SHELEST, Hanna; ZOLKINA, Mariya. 2020. Rethinking Ukraine's deoccupation policy in the context of Russia's hybrid war against Ukraine. Available online. In: https://dif.org.ua/ uploads/pdf/63175928460113b4e9dcf21.35897876.pdf Consultation date: $03 / 01 / 2021$.

KHARAZISHVILI, Yurii; KWILINSKI, Aleksy; DZWIGOL, Henryk; LIASHENKO, Viacheslav. 2021. "Strategic European integration scenarios of Ukrainian and Polish research, education and innovation spaces” In: Virtual Economics. Vol. 4, No. 2, pp. 7-40.

LEHNE, Stefan. 2020. Securing the EU's place in the world. Available online. In: https://carnegieeurope.eu/2020/11/17/securing-eu-s-place-inworld-pub-83246. Consultation date: 03/04/2021.

LOUGH, John; SOLONENKO, Iryna. 2016. Is Ukraine capable of a breakthrough in reforms? Available online. In: https://www.chathamhouse.org/ sites/default/files/publications/research/2016-04-05-ukraine-reformbreakthrough-lough-sononenko-ukrainian-final.pdf. Consultation date: 03/04/2021.

MOSKAL, Rostyslav. 2021. "Rule of law doctrine: the status of scientific study in Ukraine (2010-2020)" In: Naukovij Visnik Nacional'noi Akademii Vnutrisnih Sprav. Vol. 117, No. 4, pp.100-111.

NATIONAL DEMOCRATIC INSTITUTE. 2021. NDI Poll: Opportunities and challenges facing Ukraine's democratic transition. Available online. In: https://www.ndi.org/publications/ndi-poll-opportunities-andchallenges-facing-ukraine-s-democratic-transition-1. Consultation date: 03/04/2021.

ORGANISATION FOR ECONOMIC CO-OPERATION AND DEVELOPMENT. 2019. The European Union: A People-Centered Agenda. An International Perspective. OECD, 114 p. Paris, France.

POPADYNETS, Maksym Ihorovych. 2020. Realization of Law in the Context of Legal Development of Modern Ukraine: Axiological Dimension. PhD thesis. National Academy of Internal Affairs. Kyiv, Ukraine.

RAZUMKOV CENTRE. 2021. Ukraine-EU Partnership in the Security Sphere. Razumkov Centre, 71 p. Kyiv, Ukraine.

STEFANISHYNA, Olga. 2020. European integration 2.0: what does the updated Association Agreement with the EU offer to Ukraine? Available online. In: https://www.eurointegration.com.ua/rus/ experts/2020/07/29/7112658/. Consultation date: 03/04/2021. 
Elvira $M$. Gerasymova, Svitlana V. Kutsepal, Zorina S. Vykhovanets, Olena P. Kravchenko y Nataliia F. Yukhymenko

80

European Union as a Set of New Values in State-Building Processes in EU Enlargement Candidate

UNITED NATIONS UKRAINE. 2020. Assessment of the socio-economic impact of COVID-19 in Ukraine. Available online. In: https://ukraine. un.org/sites/default/files/2020-12/UN\%20SEIA\%20Report\%20 2020\%20\%281\%29.pdf. Consultation date: 03/04/2021.

UNITED NATIONS UKRAINE. 2021. Ukraine common country analysis. Available online. In: https://ukraine.un.org/sites/default/ files/2021-05/UN\%20CCA\%20Ukraine_April\%202021\%20\%281\%29. pdf. Consultation date: 03/04/2021.

VERKHOVNA RADA OF UKRAINE. 1994. Partnership and cooperation agreement between Ukraine and the European Communities and their member states. Available online. In: https://zakon.rada.gov.ua/laws/ show/998_012\#Text. Consultation date: 03/04/2021.

VERKHOVNA RADA OF UKRAINE. 2014. Association Agreement between Ukraine on one side and the European Union, the European Atomic Energy Community and their member states on the other side. Available online. In: https://zakon.rada.gov.ua/laws/show/984_o11\#Text. Consultation date: 03/04/2021.

WOLCZUK, Kataryna. 2019. "State building and European integration in Ukraine” In: Eurasian Geography and Economics, Vol. 6o, No. 6, pp. 1-19.

WORLD JUSTICE PROJECT. 2020. Rule of law index. Available online. In: https://worldjusticeproject.org/sites/default/files/documents/WJPROLI-2020-Online_o.pdf. Consultation date: 03/04/2021.

WORLD JUSTICE PROJECT. 2021. The four universal principles. Available online. In: https://worldjusticeproject.org/about-us/overview/whatrule-law. Consultation date: 03/04/2021.

YAKYMENKO, Yuriy (Ed.). 2020. The Razumkov Centre's Analytical Report. National Security and Defence, Vol. 1-2. Razumkov Centre. Kyiv, Ukraine.

YERMOLENKO, Volodymyr. 2020. Do European values still matter in Ukraine? Available online. In: https://www.eurozine.com/do-european-valuesstill-matter-in-ukraine/. Consultation date: 03/04/2021. 

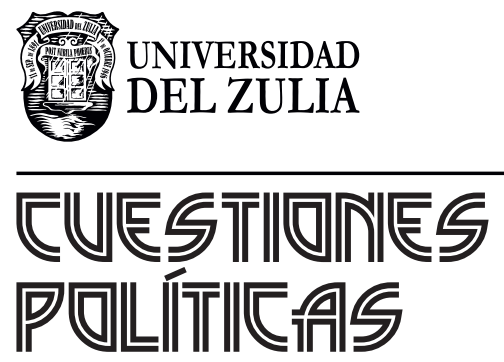

Vol. 39 N $^{\circ} 71$

Esta revista fue editada en formato digital y publicada en diciembre de 2021, por el Fondo Editorial Serbiluz, Universidad del Zulia. Maracaibo-Venezuela 